\title{
Systemic effects of periodontitis treatment in patients with type 2 diabetes: a 12 month, single-centre, investigator-masked, randomised trial
}

\author{
Francesco D'Aiuto, Nikolaos Gkranias, Devina Bhowruth, TauseefKhan, Marco Orland, Jean Suvan,Stefano Masi, Georgios Tsakos, Stevt
} Hurel, Aroon D Hingorani_ Nikos Donos, John E Deanfield, for the TASTE Groupt

\begin{abstract}
Summary
Background Chronic inflammation is believed to be a major mechanism underlying the pathophysiology of type 2 diabetes. Periodontitis is a cause of systemic inflammation. We aimed to assess the effects of periodontal treatment on glycaemic control in people with type 2 diabetes.
\end{abstract}

Methods In this 12 month, single-centre, parallel-group, investigator-masked, randomised trial, we recruited patients with type 2 diabetes, moderate-to-severe periodontitis, and at least 15 teeth from four local hospitals and 15 medical or dental practices in the UK. We randomly assigned patients (1:1) using a computer-generated table to receive intensive periodontal treatment (IPT; whole mouth subgingival scaling, surgical periodontal therapy [if the participants showed good oral hygiene practice; otherwise dental cleaning again], and supportive periodontal therapy every 3 months until completion of the study) or control periodontal treatment (CPT; supra-gingival scaling and polishing at the same timepoints as in the IPT group). Treatment allocation included a process of minimisation in terms of diabetes onset, smoking status, sex, and periodontitis severity. Allocation to treatment was concealed in an opaque envelope and revealed to the clinician on the day of first treatment. With the exception of dental staff who performed the treatment and clinical examinations, all study investigators were masked to group allocation. The primary outcome was between- group difference in $\mathrm{HbA}$, at 12 months in the intention-to-treat population. This study is registered with the ISRCTN registry, number ISRCTN83229304.

Findings Between Oct 1, 2008, and Oct 31, 2012, we randomly assigned 264 patients to IPT $(n=133)$ or CPT (n=131), all of whom were included in the intention-to-treat population. At baseline, mean HbA, was 8-1\% (SD 1-7) in both groups. After 12 months, unadjusted mean $\mathrm{HbA}_{1}$, was 8-3\% (SE 0-2) in the CPT group and 7-8\% (0.2) in the IPT group; with adjustment for baseline $\mathrm{HbA}_{1}$, age, sex, ethnicity, smoking status, duration of diabetes, and BMI, HbA, was 0-6\% (95\% Cl 0-3-0-9; p<0-0001) lower in the IPT group than in the CPT group. At least one adverse event was reported in 30 (23\%) of 133 patients in the IPT group and $23(18 \%)$ of 131 patients in the CPT group. Serious adverse events were reported in $11(8 \%)$ patients in the IPT group, including one (1\%) death, and 11 (8\%) patients in the CPT group, including three (2\%) deaths.

Interpretation Compared with CPT, IPT reduced $\mathrm{HbA}_{1}$, in patients with type 2 diabetes and moderate-to-severe periodontitisafter 12 months. These results suggest that routine oral health assessmentand treatment of periodontitis could be important for effective management of type 2 diabetes.

Funding Diabetes UK and UK National Institute for Health Research.

\section{Introduction}

The worldwide epidemic of type 2 diabetes is a major cause of disability and premature mortality, mainly from vascular and renal complications.' Inflammation can affect glycaemic control in patients with diabetes and is implicated in atherosclerosis and chronic kidney disease.' However, whether effective control of systemic inflammation can improve glycaemic control in people with type 2 diabetes and thereby reduce their risk of diabetes complications remains unclear.

Periodontitis is a chronic inflammatory disease, which often coexists with diabetes.' It is caused by a dysbiosis of the oral microbiota and is associated with a dysregulated immune-inflammatory response.' The response induced by accumulation of bacteria on the tooth surface is not only confined to the oral cavity, but is also associated with systemic inflammation.' The elevated systemic inflammatory burden in people with periodontitis has been associated with increased risk of chronic and potentially life-threatening diseases including diabetes, cardiovascular disease, and end-stage renal failure $\mathbf{I}$

Periodontal therapy is usually delivered over three phases: an initial phase, a corrective phase, and a fina supportive phase. During the initial phase, any essentia] dental care, oral hygiene advice, and teeth cleaning (scaling of the teeth, including subgingival root debridement) are 


\section{Research In context}

Evidence before this study

To identify intervention trials and systematic reviews on the effects of periodontal treatment on metabolic control in patients with type 2 diabetes published before the start of this trial we searched PubMed for reports published in English between database inception and Dec 31, 2006. We used the following search terms: "diabetes", "periodontal", "periodontitis", "treatment", "clinical triar, "systematic review", and "meta-analysis". Pooled estimates from metz analyses of small intervention trials showed a slight improvement in metabolic control after non-surgical periodontal treatment (HbA 12 reduced by around 0-3-0-4 percentage points compared with control periodontal therapy). Large heterogeneity among clinical trialswas a major limitation due to inclusion of trials including patientswith type 1 and type 2 diabetes variable follow-up times (up to 6 months), and different treatment modalities. Small sample sizes were also a limitation in these earlier studies.

\section{Added value of thls study}

Our aim was to show whether effective periodontal treatment would affect metabolic status in patients with type 2 diabetes. On the basis of the high risk for cardiovascular and renal complications reported in patients with type 2 diabetes we also investigated the effect of periodontal treatment on vascular and renal functions. This is the first study to show that periodontal treatment improves metabolic control (reducing $\mathrm{HbA}_{x}$ and plasma glucose concentrations) and vascular and kidney functions, reduces systemic inflammation. and improves quality of life in patients with type 2 diabetes after 12 months.

\section{Implications of all the avallable evidence}

A 2015 Cochrane systematic review concluded that non-surgical periodontal therapy has short-term effects on metabolic control in patients with type 2 diabetes, but noted that longer controlled dinical trials were needed to confirm long-term effects. The Cochrane review included three studies with small sample sizes that had 12 months follow-up after periodontal therapy, the results of which suggested a positive effect on metabolic control. Our study shows that periodontal treatment has beneficial effects on metabolic control in patients with type 2 diabetes over 12 months. Our results suggest a causal relation between periodontitis and control of diabetes and its key complications. Oral health promotion in patientswith type 2 diabetes is a novel and potentially beneficial therapeutic opportunity. Diabetes care providers should discuss the importance of oral health with their patients and consider incorporating routine dental assessment and treatment into lifelong preventive programmes. done. At least 8 weeks after the dental cleaning sessions, a re-evaluation of the periodontal condition is done, together with an assessment of the patient's selfperformed oral hygiene. The corrective phase of therapy includes additional surgical periodontal therapy (if oral hygiene is optimum) or a repetition of the scaling and root debridement (if oral hygiene is suboptimum). This second phase is usually completed within 1-2 months; therefore, at around 3 months after the final periodontal surgical session, a reassessment is done to enable selection of the third phase of therapy the

phase. This final phase is an open-ended protocol of sessions, usually every 3 months, that includes oral hygiene advice and professional non-surgical dental cleaning as required.

We have previously shown that treatment of periodontitis results in substantial reduction of systemic inflammatory markers and improved conduit artery endothelial function at 6 months, which is regarded as an early indicator of atherosclerosis. ${ }^{7}$ Previous studies have investigated the effect of periodontitis treatment on short-term (2-6 months' follow-up) glycaemic control in patients with diabetes, with significant reductions of $\mathrm{HbA}$, ofO $3-0.4$ percentage points being reported." However, these studies often had low numbers of participants and included a mixture of patients with type 1 and 2 diabetes; some studies were done with adjuvant local or systemic antimicrobial drugs. ${ }^{9}$ Furthermore, the ineffectiveness of non-surgical periodontal therapy in patients with diabetes has been debated as one of the major confounders of the association between the two disorders. The potential benefits of periodontitis treatment on diabetes complications therefore remain unknown.

Our group previously showed that intensive periodontal therapy was needed to observe a systemic benefit.l We hypothesised that effective treatment of periodontitis, in which local and systemic inflammation are reduced, would improve glycaemic control in patients with type 2 diabetes, thereby enhancing vascular and renal function and quality oflife.

\section{Methods}

\section{Study design and participants}

We did a 12 month, single-centre, parallel-group, investigator-masked, randomised trial to assess the effect of intensive periodontal therapy (non-surgical and surgical) compared with usual care (the care provided at regular dental check-ups - namely, cleaning and polishing the part of the tooth that is visible above the gingiva). We enrolled consecutive patients into the study if they had type 2 diabetes (using WHO diagnostic criteria) for

6 months or longer, ${ }^{10}$ moderate-to-severe periodontitis $(; 0,20$ periodontal pockets with probing pocket depths of $>4 \mathrm{~mm}$ and marginal alveolar bone loss of $>30 \%$ ), and at 
so that eligible participants would present with active signs of gingival inflammation rather than history of breakdown of periodontal soft and hard tissues. We recruited eligible participants from among referrals to the Eastman Dental Hospital (Periodontology Unit). University College Hospital (outpatients ofthe Departmen1 of Endocrinology), and Ealing and St Mary's Hospitals in London, UK. Patients were additionally recruited from 15 general medical or dental practices in the Greater London area (identified using registration data from the Diabetes Research Network). Exclusion criteria were uncontrolled systemic diseases other than diabetes (cardiovascular diseases [including hypertension], liver diseases, pulmonary diseases, end-stage renal failure, or neoplasm); hepatitis B or HIV infection; chronic treatment ( $>2$ weeks) with drugs known to affect periodontal tissues (phenytoin or ciclosporin); chronic systemic antibiotic treatment; and pregnancy or lactation. All participants provided written informed consent. The study was approved by the joint University College LondonjUniversity College London Hospital Committees on Ethics of Human Research (Committee A) in November, 2007 (Ref07fH0714j97). The original protocol was amended and re-approved by the same committee in July, 2008, April, 2010, and June, 2010.

A steering committee group met every 3 months to monitor study progress. The results ofthis meeting were communicated with an independent safety monitoring group, which reviewed any progression of periodontitis throughout the trial. No interim analyses were planned.

\section{Randomisation and masking}

We randomly assigned patients (1:1) using a computergenerated table to receive intensive periodontal treatment (IPT) or control periodontal treatment (CPT). Treatment allocation included a process of minimisation, ${ }^{11}$ taking account of diabetes duration, smoking status, sex, and severity of periodontitis. Allocation to treatment was concealed in an opaque envelope and revealed to the clinician and patient on the day of first treatment. With the exception of the study dental staff delivering the treatment and performing the clinical examinations, all other investigators (vascular examiner, nurses collecting anthropometric measures and blood samples, laboratory staff who analysed the serum samples, staff involved with the data collection and analyses, and report authors) were masked to the group allocation.

\section{Procedures}

Essential dental care, including oral hygiene instructions and removal of compromised teeth, was done in both IPT and CPT groups (appendix). Teeth were extracted if they were deemed unsalvageable: ie, if their prognosis was very poor despite restorative efforts, the surrounding jaw bone was lost in dose proximity to the tip of the root of the tooth (apex), the teeth were mobile (grade Ill), or there was a radiographic translucency around the root tip (possibly on a tooth that had undergone previous root canal treatment), which indicates unhealed jaw bone and possible abscess and pus flow.

Patients in the IPT group received an initial single session of whole mouth scaling ofthe root surfaces under local analgesia, with no time limit set for the duration of the session. 2 months after the first whole mouth scaling session, patients with good oral hygiene (dental plaque scores of ,;20\%) and at least one $6 \mathrm{~mm}$ or deeper residual periodontal pocket had periodontal surgical therapy to improve access for root surface deaning.u Patients who still had suboptimum oral hygiene or did not have residual $6 \mathrm{~mm}$ or deeper periodontal pockets at 2 months received additional scaling of the root surfaces under local analgesia. All patients in the IPT group subsequently received further sessions of scaling of the root surfaces under local analgesia every 3 months until completion of the study.

Patients in the CPT group received supra-gingival scaling and polishing of all dentition at the same timepoints as the IPT group (after baseline and at 2, 6, 9, and 12 months after the completion of the first session of periodontal therapy). At the end of the study, patients in the CPT group received any additional periodontal therapy that was required. Patients who showed progression of periodontitis" at any point received prompt specialist care and were withdrawn from the study.

Patients were allocated to clinicians in a random order using a computer-generated sequence to minimise treatment bias. Diabetes treatment was managed by the local endocrinology consultant and nurses using standard clinical guidelines in both groups, and diabetes clinicians were unaware of group assignment throughout the study. Patients were asked not to discuss their study group allocation with diabetes care professionals or the other study investigators. Only the treatment clinician discussed details of the assigned treatment with the patient. The clinical team delivering periodontal therapy in both groups included two dental hygienists, two dentists, and three periodontists (appendix). Two trained and calibrated examiners collected medical and dental histories at baseline, and measured periodontal and clinical parameters at baseline and at each study visit, as previously described. Periodontal parameters included gingival probing depth and recession of the gingival margin relative to the cementa-enamel junction at six sites per tooth; presence or absence ofsupra-gingival dental plaque and gingival bleeding on probing; averaged whole mouth number of periodontal lesions (probing depth of $>4 \mathrm{~mm}$ ); and relative percentages of presence of gingival bleeding (full mouth gingival bleeding scores [number of sites with gingival bleeding on probingjtotal number of sites per mouthxlOO]) and supra-gingival dental plaque (full mouth plaque scores [number of sites with visible detectable plaquejtotal number of sites per mouth $\times 100])$. Clinical parameters included tobacco exposure (current, former, or never smoker), blood pressure, height, bodyweight, waist circumference, and body-fat mass (data not reported). 
Medication use was collected at baseline by detailed interview and prescription assessment and reviewed a1 study visits using a detailed medication log. Semiquantitative food frequency questionnaires (detailed analyses taking into account the basal metabolic rate are to be reported elsewhere); self-reported data on general health (data not presented); and questionnaires to assess diabetes-related quality of life (Audit of Diabetes Dependent Quality ofLife), l' oral health (Oral Impacts on Daily Performance), and oral health-related quality oflife (data not presented) were administered at baseline and at 12 months. Examiner calibration exercises were repeated every 6 months for the duration of the study.

Fasting blood samples were collected at baseline and at study visits. Samples were centrifuged and stored within $1 \mathrm{~h}$ of collection. All plasma aliquots were stored at $-70 \mathrm{oC}$ for analysis at the end of the study. HbAk was measured using liquid chromatography. Concentrations of glucose, standard lipid fractions (total cholesterol, HDL cholesterol, LDL cholesterol, and triglycerides), and insulin were measured using standard assays and an automated analyser (Cobas 8000 analyser, Roche, Mannheim, Germany). Homeostasis Model Assessment (HOMA2) scores were calculated. Serum C-reactive protein (CRP) concentrations were determined by immunoturbidimetry (Cobas Integra 700, Roche, Mannheim, Germany). Full blood differential count was assessed using standard biochemical tests in real time on the day of collection. The remaining assays were performed on stored samples at the end of the study. Inflammatory

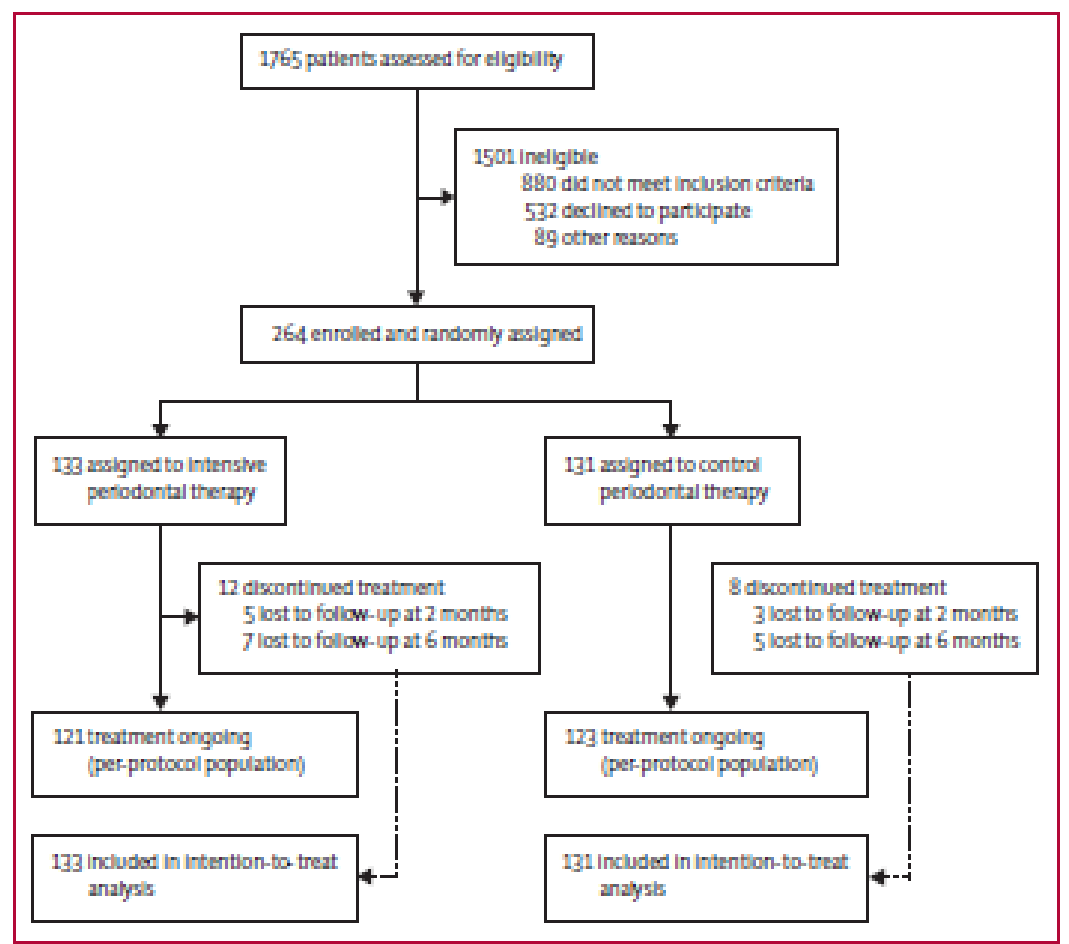

Rgure 1: Trial profile biomarkers (interleukin $1 \mathrm{p}$, interleukin 6 , interleukin 8 , interleukin 10 , interleukin 12 , interferon $\mathrm{y}$, and tumour necrosis factor $a[\mathrm{TNFa})$ ) and endothelial cell surface markers (E-selectin, P-selectin, intercellular adhesion molecule 3, and thrombomodulin) were measured by multiplex assay (Meso Scale Discovery, Rockville, MD, USA; interassay and intra-assay coefficients of variation $<7 \%$ ). Serum creatinine was measured on an automated analyser (Cobas 8000). Estimated glomerular filtration rate (eGFR) was calculated using the four-variable Modification in Diet in Renal Disease equation."

Endothelium-dependent and endothelium-independent flow-mediated dilatation (FMD) was assessed by ultrasound imaging ofthe brachial artery with a high resolution probe $(7 \mathrm{MHz})$, as previously described. ${ }^{16} 10$ year coronary heart disease and stroke risk scores were calculated at baseline and at 12 months using the UK Prospective Diabetes Study (UKPDS) Risk Engine.

\section{Outcomes}

The prespecified primary outcome was the difference in HbAk between the IPT and CPT groups at 12 months. Prespecified secondary endpoints reported here were differences between groups in HbAk at 6 months; glucose, insulin, and creatinine concentrations and FMD at 6 and 12 months; adverse events reported at study visits (defined as any changes in anatomical, physiological, or metabolic functions occurring in any phase of the clinical study: whether or not associated with the study); periodontal clinical parameters, lipid fractions, and inflammatory and endothelial cell surface markers at 2, 6, and 12 months: and eGFR and patient-reported outcomes at 12 months, including overall caloric intake and quality oflife (Audit of Diabetes Dependent Quality of Life scores). Prespecified secondary outcomes to be reported elsewhere were between-group differences in dental plaque composition, laser Doppler flowmetry, intima-media thickness, and endothelium pulse amplitude tonometry.

We did post-hoc analyses of the following endpoints: between-group differences in HOMA2 scores at baseline and at 6 and 12 months after therapy; between-group differences in 10 year cardiovascular risk scores at baseline and at 12 months; between-group differences in change in diabetes medications (including dose increase and decrease) and systemic antibiotic use from each study visit to the next; and whole-group correlation analyses between metabolic, inflammatory, kidney, and periodontal parameters at 6 and 12 months.

\section{Statistical analysis}

We calculated that a minimum sample size of 129 participants per group was needed to detect a difference in $\mathrm{HbA}_{1}$, of 1 percentage point (SD 2-1) at 12 months between groups, with an $a$ of $0-05$ and $95 \%$ power (assuming a $10 \%$ loss to follow-up).

Data are reported as mean and $\mathrm{SD}$, unless otherwise specified. We did all analyses in the intention-to-treat 
population and used the last measure carried forward approach for missing values. We repeated the analyses of all primary and secondary outcomes using post-hoc missing-value analyses with linear digital interpolation. A per-protocol population was defined as all participants in the intention-to-treat population who had at least one assessment of efficacy deemed to be unaffected by protocol violations. We did per-protocol analyses for all outcomes; the estimates derived from these analyses are reported for the primary outcome (HbA") and any secondary or post-hoc outcomes if they differed from estimates obtained in the intention-to-treat population.

We modelled the primary and secondary outcomes using multilevel linear regression with the xtmixed command in Stata (version 13; StataCorp, College Station, TX, USA). ${ }^{17}$ The models included the respective baseline measurement, treatment group (represented by one

\begin{tabular}{|c|c|c|}
\hline & $\begin{array}{l}\text { Intensive } \\
\text { periodontal } \\
\text { therapy }(n \bullet 133)\end{array}$ & $\begin{array}{l}\text { Control } \\
\text { periodontal } \\
\text { therapy } \\
(\mathrm{n}=131)\end{array}$ \\
\hline Age (years) & $58-2(9-7)$ & $555(10-0)$ \\
\hline \multicolumn{3}{|l|}{ Sex } \\
\hline Male & $82(62 \%)$ & $83(63 \%)$ \\
\hline Female & $51(38 \%)$ & $48(37 \%)$ \\
\hline \multicolumn{3}{|l|}{ Ethnicity } \\
\hline White & $43(32 \%)$ & $52(40 \%)$ \\
\hline Asian & $54(41 \%)$ & $43(33 \%)$ \\
\hline African & $25(19 \%)$ & $34(26 \%)$ \\
\hline Other & $11(8 \%)$ & $2(2 \%)$ \\
\hline \multicolumn{3}{|l|}{ Smoking history } \\
\hline Never & $75(56 \%)$ & $70(53 \%)$ \\
\hline Current & $18(14 \%)$ & $19(15 \%)$ \\
\hline Former & $40(30 \%)$ & $42(32 \%)$ \\
\hline \multicolumn{3}{|c|}{ Family history of cardiovascular diseases* } \\
\hline Positive & $60(45 \%)$ & $61(47 \%)$ \\
\hline Negative & $73(55 \%)$ & $70(53 \%)$ \\
\hline Diabetes duration (years) & $8 \cdot 3(7-4)$ & 8-7 (8-4) \\
\hline BMI $\left(\mathrm{kg} / \mathrm{m}^{\prime}\right)$ & $30(5)$ & $31(6)$ \\
\hline Waistcircumference $(\mathrm{cm})$ & $104(13)$ & $103(14)$ \\
\hline Systolic blood pressure $(\mathrm{mm} \mathrm{Hg})$ & $135(16)$ & $136(17)$ \\
\hline Diastolic blood pressure ( $\mathrm{mm} \mathrm{Hg}$ ) & $82(10)$ & $83(9)$ \\
\hline Flow-mediated dil atation & $3-9 \%(2 \cdot 5)$ & $3.9 \%(2 \cdot 5)$ \\
\hline $\mathrm{HbA}_{2}(\%)$ & $8-1 \%(1-7)$ & $8-1 \%(1-7)$ \\
\hline $\mathrm{HbA},(\mathrm{m} \mathrm{mol} / \mathrm{mol})$ & $64-6(19-1)$ & $65-4(18-8)$ \\
\hline Fasting glucose (mmoi!L) & $7-8(6-5-9-8)$ & $7-8(6-3-9 \cdot 7)$ \\
\hline Fasting insulin (miU/L) & $12-8(7-3-20-4)$ & $11-8(8-0-$ \\
\hline 19-3) HOMA2-cell function & $21-23(34-13)$ & $19-82(18-12)$ \\
\hline HOMA2 insulin sensitivity & $\begin{array}{l}558-15 \\
(848 \cdot 23)\end{array}$ & $\begin{array}{l}585-98 \\
(904 \cdot 24)\end{array}$ \\
\hline HOMA2 insulin resistance & $0-37(0-48)$ & $0-38(0-57)$ \\
\hline Insulin use at baseline & $32(24 \%)$ & $32(24 \%)$ \\
\hline Insulin daily dose at baseline (IU) & $52(37)$ & $61(42)$ \\
\hline \multirow[t]{2}{*}{ Total chol esterol (mmoi/L) } & $42(1 \cdot 0)$ & $43(1-1)$ \\
\hline & (Table contir & $\mathrm{s}$ in next column) \\
\hline
\end{tabular}

dummy variable), stage of study visit (ie, at baseline, 2 months [if included], 6 months, and 12 months), and a treatment time interaction term as explanatory variables (covariates). Additional covariates included age, sex, ethnicity, smoking status, duration of diabetes, and BMI. We applied a multilevel model with random intercepts, which included logarithmic transformation of the data where appropriate, to all continuous biomarker outcomes (secondary outcomes). A model with random intercepts and unstructured variance-covariance was used because of the reduced SEs of within-participant and betweenparticipant variance to all secondary outcomes. We did not adjust for multiple comparisons. Differences between study groups for primary and secondary outcomes at all study follow-up points $(2,6$, and 12 months) were adjusted for respective baseline values, whereas the absolute values for each treatment group at a given timepoint were not.

\begin{tabular}{|c|c|c|}
\hline \multirow{2}{*}{\multicolumn{2}{|c|}{ (Continued from previous column) }} & $\begin{array}{l}\text { Control } \\
\text { periodontal } \\
\text { therapy } \\
(\mathrm{n}=131)\end{array}$ \\
\hline & & \\
\hline Triglycerides (mmoi!L) & $1-6(1-2)$ & $1-6(1-1)$ \\
\hline LDL cholesterol (mmoi!L) & $2-2(0 \cdot 9)$ & $2-4(0 \cdot 9)$ \\
\hline HDL cholesterol (mmoi/L) & $1-2(0 \cdot 4)$ & $1 \cdot 3(0 \cdot 4)$ \\
\hline Creatinine se rum (fJmoi/L) & $81-2(19-4)$ & $80-9(22.9)$ \\
\hline eGFR $\left(\mathrm{ml} / \mathrm{min}\right.$ per $\left.1-73 \mathrm{~m}^{\prime}\right)$ & $91 \cdot 0(22-4)$ & $90-4(22 \cdot 5)$ \\
\hline $\begin{array}{l}\text { UKPDS } 10 \text {-year cardiovascular } \\
\text { disease risk }\end{array}$ & $14.3 \%(14.5)$ & $\mathbf{1 5 . 5 \%}(14.2)$ \\
\hline (-reactive protein $(\mathrm{mg} / \mathrm{L})$ & $\begin{array}{c}1-50 \\
(0-90-3 \cdot 80)\end{array}$ & $\begin{array}{c}1-80 \\
(0-80-3 \cdot 50)\end{array}$ \\
\hline Interfe ron y $(\mathrm{pg} / \mathrm{ml})$ & $2 \cdot 3(2 \cdot 7)$ & $3 \cdot 5(13 \cdot 5)$ \\
\hline Interleukin $10(\mathrm{pg} / \mathrm{ml})$ & $6-8(4 \cdot 3)$ & $6-9(5 \cdot 3)$ \\
\hline Interleukin $12(\mathrm{pg} / \mathrm{ml})$ & $2-0(7-1)$ & $7-5(54 \cdot 2)$ \\
\hline Interleukin 6 (pg/ml) & $2-0(1 \cdot 7)$ & $2 \cdot 3(2 \cdot 0)$ \\
\hline Interleukin $8(\mathrm{pg} / \mathrm{ml})$ & $15-4(9 \cdot 9)$ & 17-0(12-2) \\
\hline E-selectin (pg/ml) & $42-0(34-0)$ & $45 \cdot 1(39 \cdot 0)$ \\
\hline P-selectin $(\mathrm{pg} / \mathrm{ml})$ & $136 \cdot 9(66-3)$ & $139-7(65-4)$ \\
\hline slCAM3 (pg/m L) & $6-2(8-4)$ & $6-0(7-9)$ \\
\hline Thrombomodulin (pg!ml) & $12.9(13-9)$ & $13-4(14-9)$ \\
\hline Whole mouth plaquescores & $74 \%$ (18) & $75 \%$ (18) \\
\hline Whole mouth bleeding scores & $65 \%(19)$ & $65 \%(21)$ \\
\hline $\begin{array}{l}\text { Mean periodontal probing depth } \\
(\mathrm{mm})\end{array}$ & $3 \cdot 9(0-7)$ & $3 \cdot 9(0-8)$ \\
\hline $\begin{array}{l}\text { Number of periodo ntal pockets } \\
>\mathbf{4} \mathbf{m m}\end{array}$ & $50(22)$ & $55(27)$ \\
\hline $\begin{array}{l}\text { Percentage of periodontal } \\
\text { pockets }>4 \mathrm{~mm}\end{array}$ & $34 \%(16)$ & $35 \%(16)$ \\
\hline $\begin{array}{l}\text { Number of periodo ntal pockets } \\
>6 \mathrm{~mm}\end{array}$ & $26(24)$ & $24(19)$ \\
\hline Number of teeth & $26(4)$ & $26(4)$ \\
\hline \multicolumn{3}{|c|}{$\begin{array}{l}\text { Data are mean (SD), } n(\%) \text {, or median (IQR). HOMA2=Homeostasis Model } \\
\text { Assessment 2. eGFR=est imated glomerular filtration rate. UKPDS=UK Prospective } \\
\text { Diabetes Study. siCAM3=soluble intercell ular achesion molecule3. } \bullet \text { Heart } \\
\text { attack, stroke, or hypertension. }\end{array}$} \\
\hline
\end{tabular}


We did Spearrnan-rank correlation analyses of differences in all primary and secondary outcomes.

We did a post-hoc sensitivity analysis for the primary outcome in subgroups based on use of medications othe1 than glucose-lowering drugs. We also did a post-hoc subgroup analysis by periodontal treatment subgroup (defined as IPT with non-surgical and surgical treatment. IPT with non-surgical treatment, and CPT) assessing the differences between each treatment subgroup in $\mathrm{HbAk}, \mathrm{CRP}$ and TNFa concentrations, and clinical periodontal parameters at the 12 month visit. Lastly, we determined the proportions of patients in each study grour who achieved either a reduction in $\mathrm{HbAk}$ of at least 0.4 percentage points or a reduction of at least 0.9 percentage points at 12 months (X2 comparison).

For all analyses, a two-sided $\mathrm{p}$ value ofless than $0.0 \mathrm{OS}$ was regarded as significant.

This study was retrospectively registered on the ISRCTN registry, number ISRCTN83229304, on June 18, 2010, and amended on May 26, 2017.

\section{Role of the funding source}

The funder of the study had a role in study design, but had no role in data collection, data analysis, data interpretation. or writing of the report. The corresponding author had full access to all the data in the study and had final responsibility for the decision to submit for publication.

\section{Results}

Between Oct 1, 2008, and Oct 31, 2012, we screened 1765 patients with type 2 diabetes and randomly assigned 264 (300-6) of 885 eligible patients to either IPT $(n=133)$ or CPT $(n=131$; figure 1$)$. Enrolled participants were predominantly men aged between 30 and 60 years (table 1). Baseline cardiometabolic risk profiles were similar between groups (table 1). There were no major

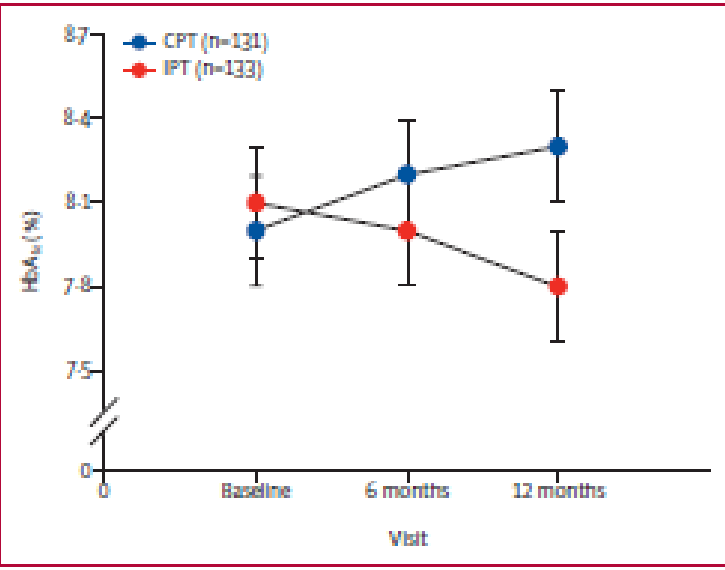

Rgure 2: $\mathrm{HbA}$ "at baseline andfollow. upvisits at 6 and 12 months Data are adjusted means and $95 \%$ Cls. p- 0.5202 for between -group difference at 6 months; $\mathrm{p}-0.0345$ for between-group difference at 12 months (no adjustmentfor baseline values, but adjusted for age, sex, ethnicity, smoking, duration of diabetes, and BMI).CPT-control periodontal treatment IPT-intensive periodontal treatment anthropometric differences between groups, and participants did not report significant changes in their lifestyles or diets (assessed as overall caloric intake) during the study. 20 (8\%) of 264 randomly assigned patients were lost to follow-up, with similar proportions in the two groups at 12 months (12 [9\%] of133 in the IPT group and eight [6\%] of 131in the CPT group; $\mathrm{p}=0 \cdot 5434)$. Differences in some diabetes medications were seen at baseline between study groups (appendix).

After the 2 month review visit (which was booked 2 months from the initial whole mouth scaling session), 63 patients with good oral hygiene (dental plaque scores of,$:: 20 \%)$ and at least one $6 \mathrm{~mm}$ or deeper residual periodontal pocket had periodontal surgical therapy to improve access for root surface cleaning. 55 patients who still had suboptimum oral hygiene and 15 patients who did not have residual $6 \mathrm{~mm}$ or deeper periodontal pockets at 2 months received additional scaling of the root surfaces under local analgesia ( $n=70$ in total).

HbAk was reduced in patients in the IPT group after 12 months of treatment compared with patients in the CPT group (figure 2). The difference in HbAk between patients in the IPT and CPT groups (adjusted for age, sex, ethnicity, smoking status, duration of diabetes, BMI, and baseline $\mathrm{HbA}, \mathrm{J}$ was $0.3 \%(95 \% \mathrm{Cl} 0.0$ to $0.5 ; \mathrm{p}=0.074)$ at 6 months and $0.6 \%(0.3$ to $0.9 ; \mathrm{p}<0.0001)$ at 12 months (table 2). Per-protocol analysis showed a non-significant difference between groups at 6 months $(0 \cdot 1 \%,-0 \cdot 3$ to $0 \cdot 5$; $\mathrm{p}=\mathrm{O} \cdot 6609)$ and a significant difference at 12 months $(0 \cdot 6 \%, 0.1$ to $1 \cdot 0 ; \mathrm{p}=0 \cdot 0101)$. Post-hoc analyses showed that $86(65 \%)$ of 133 patients in the IPT group reached a $0.4 \%$ reduction in $\mathrm{HbAk}$ at 12 months versus $47(36 \%)$ of 131 patients in the CPT group $(\mathrm{p}=0.0027)$; $89(67 \%)$ of 133 patients in the IPT group versus $43(33 \%)$ of 131 patients in the CPT group achieved a $0.9 \%$ reduction of HbAk at 12 months ( $\mathrm{p}=\mathrm{O} \cdot 0284$ ). A post-hoc sensitivity analysis in subgroups of patients based on use of medications other than glucose-lowering drugs confirmed a consistent reduction in $\mathrm{HbAk}$ in the IPT group compared with the CPT group (appendix).

At 12 months, all clinical periodontal parameters were significantly better in patients in the IPT group than in patients in the CPT group (figure 3). Full mouth dental plaque scores were $18 \%(95 \% \mathrm{Cl} 13-23$; p<0.0001) lower at 2 months, 20\% (14--25; p<0.0001) lower at 6 months, and $21 \%(15-26 ; \mathrm{p}<0.0001)$ lower at 12 months in the IPT group than in the CPT group. Full mouth bleeding scores were $16 \%(11-21 ; \mathrm{p}<0.0001)$ lower at 2 months, 24\% (19-29; p<0.0001) lower at 6 months, and $26 \%(21-31 ; p<0.0001)$ lower at 12 months in the IPT group than in the CPT group. Probing pocket depths were $0.6 \mathrm{~mm}(95 \% \mathrm{Cl} 0.4--0 \cdot 7 ; \mathrm{p}<0.0001)$ lower at 2 months and $0.8 \mathrm{~mm}(0.6-1.0 ; \mathrm{p}<0.0001)$ lower at both 6 and 12 months after therapy in patients in the IPT group than in the CPT group (appendix). The IPT group had 23 (95\% Cl 17-28; $\mathrm{p}<0.0001)$ fewer periodontal pockets with a probing pocket depth greater 


\begin{tabular}{|c|c|c|c|c|c|c|c|c|c|c|c|c|}
\hline & \multicolumn{4}{|c|}{2 months } & \multicolumn{4}{|c|}{ 6months } & \multicolumn{4}{|c|}{12 months } \\
\hline & СРТ & IPT & l'12M $(95 \% \mathrm{Cl})$ & pvalue & СРT & IPT & $\mathrm{l}^{\prime \prime 6 M}(95 \% \mathrm{CI})$ & pvalue & СРТ & IPT & l'112M (95\% Cl) & pvalue \\
\hline $\mathrm{HbA},(\%)$ & & & & & $\begin{array}{l}8-1 \% \\
(0-2)\end{array}$ & $\begin{array}{l}8-0 \% \\
(0-2)\end{array}$ & $\begin{array}{c}0-3 \\
\text { (0-0to 0-5) }\end{array}$ & $0-074$ & $\begin{array}{l}8-3 \% \\
(0-2)\end{array}$ & $\begin{array}{l}7-8 \% \\
(0-2)\end{array}$ & $\begin{array}{l}0-6 \\
(0 \cdot 3 \text { to } 0-9)\end{array}$ & $<0-0001$ \\
\hline $\begin{array}{l}\text { Total cholesterol } \\
(\mathrm{mmoi} / \mathrm{L})\end{array}$ & $\begin{array}{l}4 \cdot 1 \\
(0 \cdot 1)\end{array}$ & $\begin{array}{l}4-3 \\
(0 \cdot 1)\end{array}$ & $\begin{array}{l}0-1 \\
(-0 \cdot 2 \text { to } 0-2)\end{array}$ & $0-86$ & $\begin{array}{l}4 \cdot 2 \\
(0 \cdot 1)\end{array}$ & $\begin{array}{l}4 \cdot 3 \\
(0 \cdot 1)\end{array}$ & $\begin{array}{c}0-1 \\
(-0 \cdot 1 \text { to } 0-4)\end{array}$ & $0-33$ & $\begin{array}{l}4 \cdot 1 \\
(0 \cdot 1)\end{array}$ & $\begin{array}{l}4 \cdot 2 \\
(0 \cdot 1)\end{array}$ & $\begin{array}{l}0-0 \\
(-0-3 \text { to } 0 \cdot 3)\end{array}$ & 0.99 \\
\hline $\begin{array}{l}\text { HDL cholesterol } \\
(\mathrm{mmoi} / \mathrm{L})\end{array}$ & $\begin{array}{r}1-2 \\
(0-0)\end{array}$ & $\begin{array}{r}1-3 \\
(0-0)\end{array}$ & $\begin{array}{l}\text { Q.Q } \\
(0-0 \text { to } 0-1)\end{array}$ & $0-57$ & $\begin{array}{r}1-2 \\
(0-0)\end{array}$ & $\begin{array}{r}1-3 \\
(0-0)\end{array}$ & $\begin{array}{c}\text { Q.Q } \\
(-0-1 \text { to } 0-1)\end{array}$ & $0-58$ & $\begin{array}{c}1-3 \\
(0-0)\end{array}$ & $\begin{array}{c}1-3 \\
(0-0)\end{array}$ & $\begin{array}{l}0-1 \\
\text { (0-0to } 0-1)\end{array}$ & $0-11$ \\
\hline $\begin{array}{l}\text { LDL cholesterol } \\
(\mathrm{mmoi} / \mathrm{L})\end{array}$ & $\begin{array}{c}2 \cdot 2 \\
(0 \cdot 1)\end{array}$ & $\begin{array}{c}2-3 \\
(0 \cdot 1)\end{array}$ & $\begin{array}{l}0-0 \\
(-0-2 \text { to } 0-2)\end{array}$ & 0.71 & $\begin{array}{c}2-3 \\
(0 \cdot 1)\end{array}$ & $\begin{array}{c}2 \cdot 3 \\
(0 \cdot 1)\end{array}$ & $\begin{array}{c}0-1 \\
(-0 \cdot 1 \text { to } 0-3)\end{array}$ & $0-25$ & $\begin{array}{l}2 \cdot 2 \\
(0 \cdot 1)\end{array}$ & $\begin{array}{l}2 \cdot 2 \\
(0 \cdot 1)\end{array}$ & $\begin{array}{l}0-0 \\
(-0.2 \text { to } 0-2)\end{array}$ & $0-90$ \\
\hline Triglycericles (mmoi/L) & $\begin{array}{c}1-5 \\
(0-1)\end{array}$ & $\begin{array}{r}1-6 \\
(0-1)\end{array}$ & $\begin{array}{l}\text { Q.e } \\
(-0-2 \text { to } 0-3)\end{array}$ & $0-92$ & $\begin{array}{c}1-5 \\
(0-1)\end{array}$ & $\begin{array}{r}11 \\
(0-1)\end{array}$ & $\begin{array}{c}\text { Q.Q } \\
(-0-4 \text { to } 0-3)\end{array}$ & $0-77$ & $\begin{array}{r}1-4 \\
(0-1)\end{array}$ & $\begin{array}{r}1-6 \\
(0-1)\end{array}$ & $\begin{array}{l}-0-1 \\
(-0-4 \text { to } 0-1)\end{array}$ & $0-32$ \\
\hline $\begin{array}{l}\text { Systolic blood pressure } \\
(\mathrm{mmHg})\end{array}$ & $\begin{array}{l}132 \\
(1-4)\end{array}$ & $\begin{array}{l}131 \\
(1-4)\end{array}$ & $\begin{array}{l}1 \cdot 5 \\
(-3-4 \text { to } 6-4)\end{array}$ & 0.54 & $\begin{array}{l}133 \\
(1-4)\end{array}$ & $\begin{array}{l}131 \\
(1-4)\end{array}$ & $\begin{array}{c}3.0 \\
(-1-8 \text { to } 7 \cdot 8)\end{array}$ & $0-22$ & $\begin{array}{l}133 \\
(1-4)\end{array}$ & $\begin{array}{c}130 \\
(1-4)\end{array}$ & $\begin{array}{l}2 \cdot 3 \\
(-2-6 \text { to } 7-2)\end{array}$ & $0-35$ \\
\hline $\begin{array}{l}\text { Diastol ic blood } \\
\text { pressure (mm Hg) }\end{array}$ & $\begin{array}{l}80 \\
(0 \cdot 9)\end{array}$ & $\begin{array}{l}80 \\
(0-9)\end{array}$ & $\begin{array}{l}1-0 \\
(-2-1 \text { to } 4 \cdot 2)\end{array}$ & $0-52$ & $\begin{array}{l}80 \\
(0-8)\end{array}$ & $\begin{array}{l}81 \\
(0-8)\end{array}$ & $\begin{array}{c}-0-8 \\
(-3-4 \text { to } 1-9)\end{array}$ & $0-57$ & $\begin{array}{l}81 \\
(0 \cdot 9)\end{array}$ & $\begin{array}{l}79 \\
(0 \cdot 9)\end{array}$ & $\begin{array}{l}1-2 \\
(-11 \text { to } 4-1)\end{array}$ & $0-43$ \\
\hline BMI $\left(\mathrm{kg} / \mathrm{m}^{\prime}\right)$ & $\begin{array}{c}30-4 \\
(0.5)\end{array}$ & $\begin{array}{l}30 \cdot 1 \\
(0.5)\end{array}$ & $\begin{array}{l}0-0 \\
(-0-2 \text { to } 0-2)\end{array}$ & $0-83$ & $\begin{array}{r}30 \cdot 5 \\
(0.5)\end{array}$ & $\begin{array}{l}30 \cdot 1 \\
(0.5)\end{array}$ & $\begin{array}{c}0-1 \\
(-0 \cdot 2 \text { to } 0 \cdot 3)\end{array}$ & $0-62$ & $\begin{array}{l}30 \cdot 2 \\
(0 \cdot 5)\end{array}$ & $\begin{array}{l}30 \cdot 0 \\
(0.5)\end{array}$ & $\begin{array}{l}0-0 \\
(-0-4 \text { to } 0-4)\end{array}$ & $0-86$ \\
\hline $\begin{array}{l}\text { Waistcircumference } \\
(\mathrm{cm})\end{array}$ & $\begin{array}{l}104 \\
(1-3)\end{array}$ & $\begin{array}{l}103 \\
(1 \cdot 3)\end{array}$ & $\begin{array}{l}0-6 \\
(-2-8 \text { to } 4-1)\end{array}$ & $0-72$ & $\begin{array}{l}103 \\
(2-5)\end{array}$ & $\begin{array}{l}106 \\
(2-5)\end{array}$ & $\begin{array}{c}-3-2 \\
(-10-2 \text { to } 3-8)\end{array}$ & $0-37$ & $\begin{array}{l}105 \\
(1-3)\end{array}$ & $\begin{array}{l}104 \\
(1 \cdot 3)\end{array}$ & $\begin{array}{l}1-2 \\
(-2-3 \text { to } 4-6)\end{array}$ & $0-51$ \\
\hline Fasting insulin (miU/L) & $\begin{array}{l}20-3 \\
(4-6)\end{array}$ & $\begin{array}{l}14-6 \\
(4-6)\end{array}$ & $\begin{array}{l}4-7 \\
(-1-4 \text { to } 10-8)\end{array}$ & 0.13 & $\begin{array}{l}20-4 \\
(4-4)\end{array}$ & $\begin{array}{l}19 \cdot 0 \\
(4-4)\end{array}$ & $\begin{array}{l}-0-7 \\
(-6-3 \text { to } 4 \cdot 9)\end{array}$ & $0-80$ & $\begin{array}{l}18-0 \\
(3-1)\end{array}$ & $\begin{array}{l}17-2 \\
(3 \cdot 1)\end{array}$ & $\begin{array}{l}-1 \cdot 1 \\
(-4 \cdot 2 \text { to } 2 \cdot 0)\end{array}$ & $0-50$ \\
\hline $\begin{array}{l}\text { Flow-mediated } \\
\text { dilatation(\%) }\end{array}$ & & & & & $\begin{array}{l}3-8 \% \\
(0-3)\end{array}$ & $\begin{array}{l}5-0 \% \\
(0-3)\end{array}$ & $\begin{array}{c}-0-9 \\
(-1-2 \text { to }-0.5)\end{array}$ & $<0-0001$ & $\begin{array}{l}3-4 \% \\
(0 \cdot 2)\end{array}$ & $\begin{array}{l}4-8 \% \\
(0-2)\end{array}$ & $\begin{array}{l}-1-2 \\
(-1-5 \text { to }-0.9)\end{array}$ & $<0-0001$ \\
\hline $\begin{array}{l}\text { Fasting glucose } \\
(\mathrm{mg} / \mathrm{c} \mathrm{U} .)\end{array}$ & & & & & $\begin{array}{r}160-1 \\
(5 \cdot 2)\end{array}$ & $\begin{array}{r}148-1 \\
(5 \cdot 1)\end{array}$ & $\begin{array}{c}12 \cdot 1 \\
(2-3 \text { to } 22 \cdot 1)\end{array}$ & $0-0323$ & $\begin{array}{r}164-1 \\
(5 \cdot 2)\end{array}$ & $\begin{array}{r}151 \cdot 1 \\
(5 \cdot 1)\end{array}$ & $\begin{array}{l}12 \cdot 9 \\
\text { (3-4 to } 21-0)\end{array}$ & $0-0344$ \\
\hline Creatinine (fJmoi/L) & & & & & $\begin{array}{c}83-1 \\
(2 \cdot 0)\end{array}$ & $\begin{array}{l}80-2 \\
(2-1)\end{array}$ & $\begin{array}{c}1-8 \\
(-2 \cdot 9 \text { to } 6 \cdot 5)\end{array}$ & 0.231 & $\begin{array}{l}83-1 \\
(2-1)\end{array}$ & $\begin{array}{l}79-8 \\
(2-1)\end{array}$ & $\begin{array}{l}4-8 \\
(0 \cdot 1 \text { to } 9 \cdot 5)\end{array}$ & 0.0421 \\
\hline $\begin{array}{l}\text { eGFR (m/minper } \\
\left.1-73 \mathrm{~m}^{\prime}\right)\end{array}$ & & & & & & & & & $\begin{array}{l}87-1 \\
(2 \cdot 4)\end{array}$ & $\begin{array}{r}90-6 \\
(2-6)\end{array}$ & $\begin{array}{l}-4 \cdot 1 \\
(-6-8 \text { to }-1-4)\end{array}$ & $0-0031$ \\
\hline HOMA2-cell function & & & & & $\begin{array}{r}19 \cdot 6 \\
(2-3)\end{array}$ & $\begin{array}{l}19-6 \\
(2 \cdot 3)\end{array}$ & $\begin{array}{c}-1-6 \\
(-46 \text { to } 1.5)\end{array}$ & $0-31$ & $\begin{array}{l}17.9 \\
(1-8)\end{array}$ & $\begin{array}{l}18-7 \\
(187)\end{array}$ & $\begin{array}{c}1-8 \\
(-5 \cdot 1 \text { to } 1 \cdot 5)\end{array}$ & $0-29$ \\
\hline $\begin{array}{l}\text { HOMA2 insulin } \\
\text { sensitivity }\end{array}$ & & & & & $\begin{array}{r}444-7 \\
(53-3)\end{array}$ & $\begin{array}{l}545-6 \\
(53 \cdot 5)\end{array}$ & $\begin{array}{l}-122 \cdot 1 \\
(-265-8 \text { to } 21-5)\end{array}$ & $0-10$ & $\begin{array}{r}461-8 \\
(41 \cdot 4)\end{array}$ & $\begin{array}{r}467-9 \\
(41-6)\end{array}$ & $\begin{array}{l}0.5 \\
(-89-? \text { to } 90-6)\end{array}$ & 0.99 \\
\hline $\begin{array}{l}\text { HOMA2 insulin } \\
\text { resistance }\end{array}$ & & & & & $\begin{array}{r}0-4 \\
(0 \cdot 1)\end{array}$ & $\begin{array}{c}0-5 \\
(0 \cdot 1)\end{array}$ & $\begin{array}{c}\text { Q.Q } \\
(-0 \cdot 2 \text { to } 0-1)\end{array}$ & 0.57 & $\begin{array}{c}0-4 \\
(0 \cdot 0)\end{array}$ & $\begin{array}{c}0-4 \\
(0 \cdot 0)\end{array}$ & $\begin{array}{l}\text { Q.Q } \\
\text { (0-Oto 0-1) }\end{array}$ & $0-14$ \\
\hline $\begin{array}{l}\text { UKPD510-year } \\
\text { cardiova ular disease } \\
\text { risk }\end{array}$ & & & & & & & & & $\begin{array}{l}11-0 \% \\
(1-1)\end{array}$ & $\begin{array}{l}8-8 \% \\
(1-1)\end{array}$ & $\begin{array}{l}1 \cdot 1 \\
(1-0 \text { to } 1-2)\end{array}$ & $0-0323$ \\
\hline $\begin{array}{l}\text { Data are unad;usted mean } \\
\text { IPT=intensive periodontal } \\
\text { adjusted for basel ine value } \\
\text { OMA2=homeostasis mode }\end{array}$ & $\begin{array}{l}\text { (SE), unless } \\
\text { reatment } \\
\text { sand othe } \\
\text { assessmen }\end{array}$ & $\begin{array}{l}=\text { differen } \\
\text { ounders. } 1 \\
\text { UKPDS=U }\end{array}$ & pect ive Diabet & study. & Tgroup & $\begin{array}{l}\text { Ted fo } \\
\text { T grot }\end{array}$ & $\begin{array}{l}\text {-li ne values anc } \\
\text { adjust ed for ba }\end{array}$ & $\begin{array}{l}\text { herconfo } \\
\text { e values: }\end{array}$ & $\begin{array}{l}\text { onfou nd } \\
\text { rs. l'l6M= } \\
\text { ther conf }\end{array}$ & $\begin{array}{l}\text { PT=cont } \\
\text { rence at } \\
\text { ers. eG Fh }\end{array}$ & $\begin{array}{l}\text { io }<\text { hntal treat } \mathrm{m} \\
\text { ths between } \mathrm{CP} \\
\text { mated glomerula }\end{array}$ & $\begin{array}{l}d \mathrm{PTT} \\
\text { ration }\end{array}$ \\
\hline
\end{tabular}

than $4 \mathrm{~mm}$ than the CPT group at 2 months, 28 (23-34; $\mathrm{p}<\mathrm{O}-0001)$ fewer at 6 months, and 27 (22-32; $<<0-0001$ ) fewer at 12 months. Post-hoc missing data analyses confirmed these results (data not shown). The main reason for extraction of unsalvageable teeth related tc the study hypothesis was severe infection anc inflammation, which would affect the study results: similar average numbers of teeth were removed from each study group (the mean number ofteeth removed was 1-0 [95\% Cl 0-4--1-2)).

We saw a significant reduction in plasma fasting glucose concentrations after 6 months and 12 months of therapy in the IPT group compared with the CPT group (table 2). During the study, fasting insulin concen- trations, HOMA2 scores, and lipids concentrations did not change between groups (table 2). We found no differences in HbA" between patients in the IPT subgroups (non-surgical [n=70] vs non-surgical and surgical therapy $[n=63]$ ) in a post-hoc analysis (appendix). Post-hoc missing data analyses confirmed these results (data not shown).

CRP concentrations were significantly lower in the IPT group than in the CPT group at 2 months , 6 months, and 12 months after treatment (table 3). TNFa concentrations were significantly lower in the IPT group than in the CPT group at 6 months and 12 months (table 3: appendix). We did not see significant differences in any other inflammatory or endothelial surface $m$ arkers, 


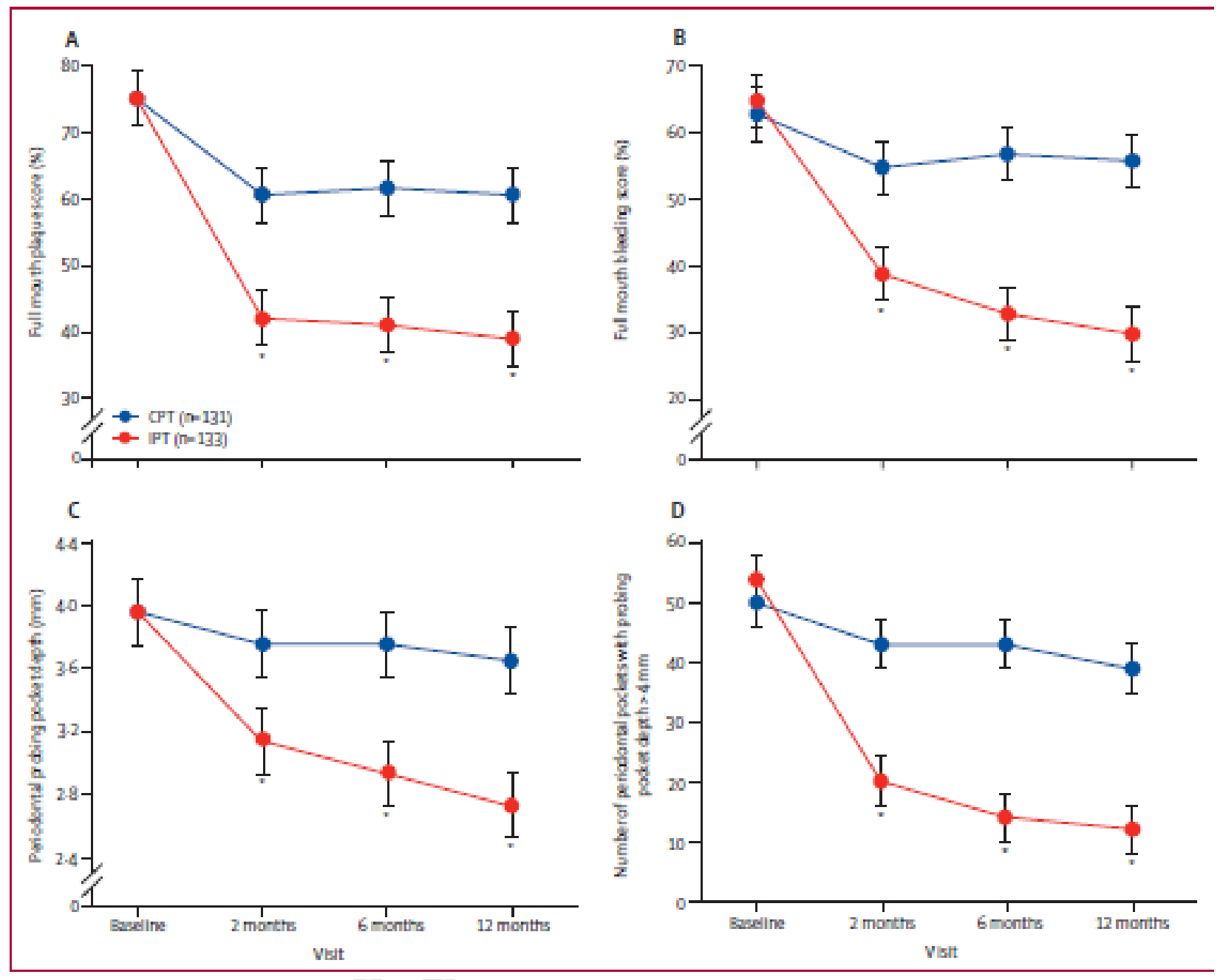

Figure 3: Periodontal measures at baseline and follow-up visits at 2,6, and 12 months

Data are adjusted meansand 95\% Cls. CPT-<:ontrol periodontal treatment IPT-intensive periodontal treatment. *Between-group differences for all peridontal measuresweresignificant at 2,6, and 12 months (all $\mathrm{p}<0 \cdot 0001$ )

apart from a difference in soluble E-selectin and P-selectin at 6 months (table 3). We saw no differences in CRP or TNFa concentrations between the IPT subgroups in the post-hoc analysis by corrective treatment subgroup (non-surgical vs non-surgical and surgical; appendix). Post-hoc missing data analyses confirmed these results (data not shown).

Patients in the 1PT group had greater FMD at 6 months and 12 months than patients in the CPT group (table 2). We saw no major differences between groups in blood pressure measures (table 2). Patients in the IPT group had a lower overall coronary artery disease 10 year risk score than patients in the CPT group at 12 months (table 2). Post-hoc missing data analyses confirmed these results (data not shown).

At 12 months, creatinine levels were significantly lower in patients who received IPT than in patients receiving CPT (table 2). At 12 months, patients in the IPT group had higher eGFR than did patients in the CPT group (table 2). Post-hoc missing data analyses confirmed these results (data not shown).
Adverse events were similar between study groups (table 4). Four serious adverse events resulted in death (one in the IPT group and three in the CPT group; $\mathrm{F}$ $0-3683$; table 4). Changes in prescribed medications ( $>20 \%$ of patients) were similar between the two study groups (appendix). No significant differences in amoun1 and type of diabetes medications post randomisation were seen between study groups. Post-hoc missing data analyses confirmed these results (data not shown).

Between-group differences in $\mathrm{HbA}^{\prime \prime}$ at 12 months correlated with those in periodontal parameters (periodontal probing depth, RO 2 ; Spearrnan-rank correlation test, pO-0074; p coefficient $0 \cdot 28,95 \% \mathrm{Cl} 0 \cdot 08$ to $0 \cdot 48$ ), kidney function (eGFR, R --0-2; Spearrnan-rank correlation test, $\mathrm{p} 0-0192 ; \mathrm{p}$ coefficient $-0-19,95 \% \mathrm{Cl}$ -0.28 to -0.03 ), and inflammatory outcomes (CRP, RO-2; Spearman-rank correlation test, p O- 0014; $\mathrm{p}$ coefficient $0-05,95 \% \mathrm{Cl} 0-01$ to $0-08$; and $\mathrm{TNFa}$, R 0-2; Spearrnan-rank correlation test, p 0-0013; p coefficient $0-06,95 \% \mathrm{Cl} 0-01$ to $0-14)$. Similarly, between-group differences in $\mathrm{CRP}$ at 12 months 


\begin{tabular}{|c|c|c|c|c|c|c|c|c|c|c|c|c|}
\hline & \multicolumn{4}{|c|}{2 months } & \multicolumn{4}{|c|}{6 months } & \multicolumn{4}{|c|}{12 months } \\
\hline & СРT & IPT & $\mathrm{I}^{\prime} 12 \mathrm{M}(95 \% \mathrm{CI})$ & pvalue & СРT & IPT & l'16M (95\% Cl) & pvalue & СPT & IPT & l'112M (95\%CI) & pvalue \\
\hline $\mathrm{CRP}(\mathrm{mg} / \mathrm{L})$ & $\begin{array}{l}3-7 \\
(0-2)\end{array}$ & $\begin{array}{c}2-7 \\
(0-2)\end{array}$ & $\begin{array}{l}1-2 \\
(1-0 \text { to } 1-4)\end{array}$ & $0-0213$ & $\begin{array}{l}4-0 \\
(0-2)\end{array}$ & $\begin{array}{l}2-8 \\
(0-2)\end{array}$ & $\begin{array}{l}1-3 \\
(0-9 \text { to } 1-7)\end{array}$ & $0-0102$ & $\begin{array}{c}3-3 \\
(0-3)\end{array}$ & $\begin{array}{l}2-4 \\
(0-2)\end{array}$ & $\begin{array}{l}1-0 \\
(0-8 \text { to } 1-2)\end{array}$ & $0-0102$ \\
\hline TNFa $(\mathrm{pg} / \mathrm{ml})$ & $\begin{array}{l}4-3 \\
(0-3)\end{array}$ & $\begin{array}{c}4-4 \\
(0 \cdot 2)\end{array}$ & $\begin{array}{l}0-2 \\
(-0-4 \text { to } 0-8)\end{array}$ & $0-67$ & $\begin{array}{l}4-6 \\
(0 \cdot 2)\end{array}$ & $\begin{array}{l}4-3 \\
(0 \cdot 2)\end{array}$ & $\begin{array}{l}0-6 \\
(0-0 \text { to } 1 \cdot 2)\end{array}$ & $0-0434$ & $\begin{array}{c}4-6 \\
(0-3)\end{array}$ & $\begin{array}{l}4 \cdot 1 \\
(0 \cdot 3)\end{array}$ & $\begin{array}{l}0-4 \\
\text { (0-2to } 0-6)\end{array}$ & $0-0201$ \\
\hline Interferon $y(\mathrm{pg} / \mathrm{ml})$ & $\begin{array}{l}2-9 \\
(0.5)\end{array}$ & $\begin{array}{r}3-4 \\
(0-5)\end{array}$ & $\begin{array}{l}-1-6 \\
(-3-1 \text { to } 0-2)\end{array}$ & $0-14$ & $\begin{array}{l}6-6 \\
(2-1)\end{array}$ & $\begin{array}{l}2-9 \\
(2-3)\end{array}$ & $\begin{array}{l}0-8 \\
(-7-0 \text { to } 8-6)\end{array}$ & $0-84$ & $\begin{array}{l}2-5 \\
(0-4)\end{array}$ & $\begin{array}{c}2-6 \\
(0-5)\end{array}$ & $\begin{array}{l}-0-7 \\
(-2-2 \text { to } 0-8)\end{array}$ & $0-37$ \\
\hline Interleukin $10(\mathrm{pg} / \mathrm{ml})$ & $\begin{array}{l}6-9 \\
(0-4)\end{array}$ & $\begin{array}{c}\mathrm{T} 3 \\
(0-4)\end{array}$ & $\begin{array}{l}-0-3 \\
(-1 \cdot 5 \text { too-8) }\end{array}$ & 0.57 & $\begin{array}{c}\mathrm{T} 3 \\
(0-4)\end{array}$ & $\begin{array}{c}\mathrm{T} 3 \\
(0-4)\end{array}$ & $\begin{array}{l}0-1 \\
(-0-8 \text { to } 1 \cdot 0)\end{array}$ & $0-86$ & $\begin{array}{l}7-6 \\
(0-6)\end{array}$ & $\begin{array}{l}8-6 \\
(0-6)\end{array}$ & $\begin{array}{l}-0 \cdot 1 \\
(-1 \cdot 9 \text { to } 1-6)\end{array}$ & $0-87$ \\
\hline Interleukin $12(\mathrm{pg} / \mathrm{ml})$ & $\begin{array}{l}3-2 \\
(1-7)\end{array}$ & $\begin{array}{l}2-8 \\
(1-8)\end{array}$ & $\begin{array}{l}0-3 \\
(-2-0 \text { to } 2-6)\end{array}$ & $0-79$ & $\begin{array}{l}3.9 \\
(1.9)\end{array}$ & $\begin{array}{l}2-5 \\
(2-1)\end{array}$ & $\begin{array}{l}0-8 \\
(-2-6 \text { to } 4 \cdot 1)\end{array}$ & $0-65$ & $\begin{array}{c}3-1 \\
(1-7)\end{array}$ & $\begin{array}{l}2-7 \\
(1-8)\end{array}$ & $\begin{array}{l}0-9 \\
(-0-8 \text { to } 2-7)\end{array}$ & $0-28$ \\
\hline Interleukin $6(\mathrm{pg} / \mathrm{ml})$ & $\begin{array}{l}2.0 \\
(0.5)\end{array}$ & $\begin{array}{l}2-6 \\
(0.5)\end{array}$ & $\begin{array}{l}-0 \cdot 9 \\
(-2 \cdot 3 \text { to } 0-5)\end{array}$ & $0-21$ & $\begin{array}{r}2 \cdot 3 \\
(0 \cdot 2)\end{array}$ & $\begin{array}{l}2-3 \\
(0 \cdot 2)\end{array}$ & $\begin{array}{l}-0 \cdot 2 \\
(-0-8 \text { to } 0.5)\end{array}$ & $0-61$ & $\begin{array}{l}2.2 \\
(0.5)\end{array}$ & $\begin{array}{l}3-1 \\
(0.5)\end{array}$ & $\begin{array}{l}-1-1 \\
(-2 \cdot 3 \text { to } 0-0)\end{array}$ & $0-06$ \\
\hline Interleukin $8(\mathrm{pg} / \mathrm{ml})$ & $\begin{array}{l}17-2 \\
(2-0)\end{array}$ & $\begin{array}{l}16-4 \\
(2-0)\end{array}$ & $\begin{array}{l}0-4 \\
(-5 \cdot 1 \text { to } 5 \cdot 9)\end{array}$ & $0-89$ & $\begin{array}{l}18.3 \\
(1-8)\end{array}$ & $\begin{array}{l}16-1 \\
(1-8)\end{array}$ & $\begin{array}{l}1-1 \\
(-3-1 \text { to } 5-8)\end{array}$ & $0-66$ & $\begin{array}{l}17-6 \\
(1-2)\end{array}$ & $\begin{array}{r}14 \cdot 9 \\
(1-2)\end{array}$ & $\begin{array}{l}2-5 \\
(-0-9 \text { to } 6-0)\end{array}$ & $0-15$ \\
\hline E-selectin $(\mathrm{pg} / \mathrm{ml})$ & $\begin{array}{c}41 \cdot 0 \\
(3-0)\end{array}$ & $\begin{array}{l}35-6 \\
(2 \cdot 9)\end{array}$ & $\begin{array}{l}-0-4 \\
(-4 \cdot 2 \text { to } 3-3)\end{array}$ & $0-82$ & $\begin{array}{l}41.9 \\
(2.7)\end{array}$ & $\begin{array}{l}33 \cdot 0 \\
(2.7)\end{array}$ & $\begin{array}{l}3 \cdot 5 \\
(0-4 \text { to } 6-7)\end{array}$ & $0-0295$ & $\begin{array}{c}43 \cdot 0 \\
(2 \cdot 9)\end{array}$ & $\begin{array}{r}36-8 \\
(2 \cdot 9)\end{array}$ & $\begin{array}{l}1 \cdot 0 \\
(-2-4 \text { to } 4-4)\end{array}$ & $0-58$ \\
\hline P-selectin $(\mathrm{pg} / \mathrm{ml})$ & $\begin{array}{r}139-0 \\
(6-8)\end{array}$ & $\begin{array}{r}133-0 \\
(6-8)\end{array}$ & $\begin{array}{l}-0-1 \\
(-13 \cdot 4 \text { to } 13-2)\end{array}$ & $0-99$ & $\begin{array}{r}140-4 \\
(6-2)\end{array}$ & $\begin{array}{r}119-1 \\
(6-2)\end{array}$ & $\begin{array}{l}15-0 \\
(3 \cdot 2 \text { to } 26-7)\end{array}$ & $0-0127$ & $\begin{array}{l}150-1 \\
(7-3)\end{array}$ & $\begin{array}{r}141-2 \\
(7-2)\end{array}$ & $\begin{array}{l}42 \\
(-8 \text { to } 17-2)\end{array}$ & $0-52$ \\
\hline siCAM3 $(\mathrm{pg} / \mathrm{ml})$ & $\begin{array}{l}5 \cdot 8 \\
(0.7)\end{array}$ & $\begin{array}{r}5 \cdot 2 \\
(0 \cdot 7)\end{array}$ & $\begin{array}{l}-0 \cdot 1 \\
(-0-7 \text { to } 0.5)\end{array}$ & $0-79$ & $\begin{array}{r}5 \cdot 9 \\
(0-6)\end{array}$ & $\begin{array}{l}4 \cdot 8 \\
(0-6)\end{array}$ & $\begin{array}{l}0.5 \\
(0-0 \text { to } 0.9)\end{array}$ & $0-06$ & $\begin{array}{c}6-4 \\
(0.7)\end{array}$ & $\begin{array}{r}5 \cdot 3 \\
(0 \cdot 7)\end{array}$ & $\begin{array}{l}0-4 \\
(-0 \cdot 3 \text { to } 1-1)\end{array}$ & $0-24$ \\
\hline lhrombomodulin (pg/ml) & $\begin{array}{l}13 \cdot 4 \\
(1-3)\end{array}$ & $\begin{array}{l}12-0 \\
(13)\end{array}$ & $\begin{array}{l}-0-4 \\
(-1-6 \text { to } 0.7)\end{array}$ & $0-44$ & $\begin{array}{c}13-2 \\
(1-2)\end{array}$ & $\begin{array}{l}10-7 \\
(1-2)\end{array}$ & $\begin{array}{l}0-7 \\
(-0-3 \text { to } 1-7)\end{array}$ & $0-16$ & $\begin{array}{l}13-6 \\
(1-2)\end{array}$ & $\begin{array}{l}11-6 \\
(1-2)\end{array}$ & $\begin{array}{l}0-3 \\
(-0-6 \text { to } 1-2)\end{array}$ & $0-52$ \\
\hline $\begin{array}{l}\text { Data are unadjusted mea n (SE } \\
\text { IPT=intensive periodontal trea } \\
\text { ad;usted for basel ine values a } \\
\text { necrosis factor a. siCAM3 }=\text { solv }\end{array}$ & $\begin{array}{l}\mathrm{d} \text { othe rco } \\
\mathrm{e} \text { intercel }\end{array}$ & $\begin{array}{l}\text { ders. l'1 } \\
\text { dhesiot }\end{array}$ & $\begin{array}{l}\text { ffere nce at } 12 \\
\text { ule3. }\end{array}$ & & & & $\begin{array}{l}\text { rbaselinevaluc } \\
\text { lues a nd other } \\
\text { ed for basel ine }\end{array}$ & . & $\begin{array}{l}\mathrm{l}=\mathrm{din} \\
\text { onfou }\end{array}$ & $\begin{array}{r}\text { ntrol } \\
6 \text { mo } \\
\text { RP=C-1 }\end{array}$ & $\begin{array}{l}\text { tal treatment } \\
\text { ween } \mathrm{CPT} \text { a nd } \\
\text { protein. } \mathrm{TNFa}=\mathrm{t}\end{array}$ & $\begin{array}{l}\text { rou ps, } \\
\text { ou r }\end{array}$ \\
\hline
\end{tabular}

correlated with those in periodontal parameters (periodontal probing depth, $\mathrm{R}=\mathrm{O} \cdot 2 ; \mathrm{S}$ pearman-rank correlation test, $\mathrm{p}=0-0062 ; \mathrm{p}$ coefficient $0 \cdot 84,95 \% \mathrm{Cl}$ 0.07 to 1.62$)$ and $T N F a(\mathrm{R}=0.3$; Spearman-rank correlation test, $\mathrm{p}<0-0001 ; \mathrm{p}$ coefficient $0 \cdot 22,95 \% \mathrm{Cl}$ $0 \cdot 10$ to $0 \cdot 54$ ), and those of TNFa correlated with periodontal parameters (periodontal probing depth $\mathrm{R}=\mathrm{O} \cdot 2$; Spearman-rank correlation test, $\mathrm{p}=\mathrm{O} \cdot 0214$; p coefficient $0 \cdot 33,95 \% \mathrm{Cl} 0 \cdot 03$ to $0 \cdot 63$ ). Lastly, changes in vascular function (FMD) correlated with improvement in periodontal parameters (periodontal probing depth $\mathrm{R}=-0 \cdot 2$; Spearman-rank correlation test, $\mathrm{p}=\mathrm{O} \cdot 0033$; $\mathrm{p}$ coefficient $-0.32,95 \% \mathrm{Cl}-0.56$ to -0.08 ; and gum bleeding scores, $\mathrm{R}=-0 \cdot 2$; $\quad$ Spearman-rank correlation test, $\mathrm{p}=0-0142 ; \mathrm{p}$ coefficient $-0 \cdot 01,95 \% \mathrm{Cl}$ $-0 \cdot 02$ to $-0 \cdot 00)$. Post-hoc missing data analyses confirmed these results (data not shown).

Overall Audit of Diabetes Dependent Quality of Life scores showed better quality of life at 12 months in patients in the IPT group than in patients in the CPT group $(0 \cdot 83,95 \% \mathrm{Cl} 0 \cdot 29-1 \cdot 38 ; \mathrm{p}=0-0034)$. This was mainly due to changes in working life (difference $1 \cdot 12$, 95\% Cl 0.37-1.86; $\mathrm{p}=0-0029$ ), self-confidence (difference $0 \cdot 48,0 \cdot 17-1 \cdot 22 ; p=0-0413)$, and living conditions (difference $0.81,0 \cdot 40-1.43 ; \mathrm{p}=0.0096$ ) domains ofthe test. Post-hoc missing data analyses confirmed these results (data not shown).

\section{Discussion}

Results of this study show that IPT improves metabolic control in patients with type 2 diabetes after 12 months compared with usual care. Reductions in HbAk and fasting plasma glucose concentrations were accompanied by improved vascular and kidney function, reduced systemic inflammation, and improved quality oflife. These results suggest a causal relation between periodontitis and diabetes control and key complications of diabetes.

Our results suggest that oral health improvement in this population represents a novel and important therapeutic opportunity. Evidence from other studies ${ }^{18}$ suggests that every percent age point reduction in $\mathrm{HbAk}$ is associated with a $21 \%$ reduction in clinically relevant endpoints, including mortality. Metforrnin represents the first-line drug in the management of type 2 diabetes, but most patients struggle to achieve meaningful improvement in metabolic biomarkers with this drug alone. In this study, periodontal treatment was used as an adjunctive therapy to traditional glucose-lowering drugs. Evidence suggests that adding a second glucoselowering drug results in an additional reduction in $\mathrm{HbA}$, , ranging between 0.4 and 0.9 percentage points. ${ }^{19}$ The effect of intensive periodontal therapy on metabolic control as seen in this study is therefore similar in magnitude to that achieved by adding a second diabetes drug. 
Many small trials and several meta-analyses have investigated the potential benefit of periodontitis treatment on glucose control, with inconclusive findings. Because most previous trials had a small sample size ( $<30$ patients per group) and short follow-up, comparison with our study is difficult. A previous trial"' of periodontal

\begin{tabular}{|c|c|c|c|}
\hline & $\begin{array}{l}\text { Intensive } \\
\text { periodontal } \\
\text { therapy }(\mathrm{n}=133)\end{array}$ & $\begin{array}{l}\text { Control } \\
\text { periodontal } \\
\text { therapy }(n=131)\end{array}$ & pvalue \\
\hline $\begin{array}{l}\text { Numberofserious } \\
\text { adverse events (any)* }\end{array}$ & & & $0-8244 t$ \\
\hline 21 & $11(8 \%)$ & $11(8 \%)$ & \\
\hline 22 & $2(2 \%)$ & $1(1 \%)$ & \\
\hline 23 & $1(1 \%)$ & $1(1 \%)$ & \\
\hline $\begin{array}{l}\text { Seriousadverse } \\
\text { evenls causing deatht }\end{array}$ & $1(1 \%)$ & $3(2 \%)$ & $0-3683$ \\
\hline $\begin{array}{l}\text { Number of adverse } \\
\text { events (any) }\end{array}$ & & & $0-3994 S$ \\
\hline 21 & $30(23 \%)$ & $23(18 \%)$ & \\
\hline 22 & $33(25 \%)$ & $38(29 \%)$ & \\
\hline 23 & $17(13 \%)$ & $18(14 \%)$ & \\
\hline 24 & $12(9 \%)$ & $\mathbf{1 7}(13 \%)$ & \\
\hline 25 & $12(9 \%)$ & $6(5 \%)$ & \\
\hline 26 & $7(5 \%)$ & $3(2 \%)$ & \\
\hline 27 & $1(1 \%)$ & $3(2 \%)$ & \\
\hline 28 & $3(2 \%)$ & $1(1 \%)$ & \\
\hline Tooth pain1) & $43(4 \cdot 0 \%)$ & $31(3 \cdot 0 \%)$ & $0-8910$ \\
\hline Tooth sensitivity1) & $33(3-17)$ & $9(0-9 \%)$ & $0-7327$ \\
\hline Tooth infectionll & $27(2-5 \%)$ & $27(2-6 \%)$ & $0-6997$ \\
\hline Vaccination1) & $21(2-0 \%)$ & $24(2.3 \%)$ & $0 \cdot 1376$ \\
\hline Chest infectionll & $13(1-2 \%)$ & $11(1-0 \%)$ & $0-5000$ \\
\hline Gum swelli ngll & $12(1-1 \%)$ & $8(0-8 \%)$ & $0-1521$ \\
\hline Tooth fracture1) & $12(1-1 \%)$ & $17(1-6 \%)$ & $0-2271$ \\
\hline Tooth restoration!! & $9(0-8 \%)$ & $12(1-1 \%)$ & $0-1332$ \\
\hline Headachel] & $8(0-8 \%)$ & $4(0-4 \%)$ & $0-5578$ \\
\hline Influenzal! & $7(0 \mathrm{lo} / \mathrm{o})$ & $7(\mathrm{Olo} / \mathrm{o})$ & $0-3618$ \\
\hline Throat infe<:tion1) & $4(0-4 \%)$ & $5(0 \cdot 5 \%)$ & $0-4145$ \\
\hline Foot infectionll & $5(0-5 \%)$ & $6(0-6 \%)$ & $0-5488$ \\
\hline Faintingll & $3(0.3 \%)$ & $3(0.3 \%)$ & $0-2733$ \\
\hline Dizzinessll & $4(0-4 \%)$ & $4(0-4 \%)$ & $0-5134$ \\
\hline Backpainll & $3(0-3 \%)$ & $5(0-5 \%)$ & $0-3882$ \\
\hline \multicolumn{4}{|c|}{ 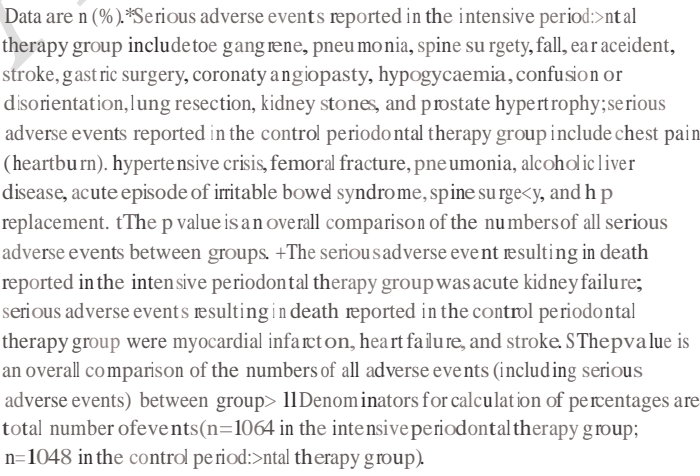 } \\
\hline
\end{tabular}

treatment and metabolic control by Sun and colleagues reported a significant reduction in $\mathrm{HbAk}$ ofO 4 percentage points after 3 months. In the trial, 157 patients with type 2 diabetes and periodontitis in at least 30\% their gingival sites were randomly assigned to periodontal treatment, including non-surgical and surgical periodontal therapy and a systemic course of antibiotics, whereas the 75 participants in the control group received no treatment. In our study, we did not measure metabolic markers until 6 months after baseline, and the IPT and CPT groups in our trial were both substantially different to the treatment and control groups, respectively, used in the trial by Sun and colleagues. Despite these differences and the high risk of bias in the study by Sun and colleagues,"' the results of the study are consistent with our findings.

Two other trials $\mathrm{s}^{21}{ }^{22}$ reported null effects of periodontal therapy on metabolic control. In the post-hoc analysis of one trial," in which 165 male participants in the US Veterans Administration programme received periodontal treatment or usual care for 4 and 12 months in : two-by-two design, HbAk was numerically lower in the treatment group, but the results were not significant: possibly due to the small sample size. Another 6 month trial $^{22}$ of 134 patients with periodontitis and type 2 diabetes involved a course of non-surgical periodontal therapy. but patients randomly assigned to the test group had an additional course of treatment after 3 months. In this trial, both treatment groups saw a reduction in $\mathrm{HbAk}$. with no significant difference between groups. The smaller sample size, the different periodontal treatments provided, and the allocation bias are the main differences between our study and this other trial.

A 2015 Cochrane review" concluded that the level of evidence for the effect of periodontal treatment in patients with type 2 diabetes is of low quality, and that any improvement in glucose control after periodontal treatment is lost after 3--4 months. The largest trial to date (the multicentre Diabetes and Periodontal Therapy Trial [DPTT], which had two study groups with 257 patients each)" showed non-significant slight improvements in periodontal health and no benefit on glycaemic control at 6 months. Several factors might account for the difference between our findings and those of the DPTT. Our study was longer (12 months vs 6 months). As in the DPTT, our primary endpoint did not reach significance at 6 months, but we did see significant differences between groups at 12 months. Additionally, participants achieved greater reductions in dental plaque and gingival bleeding scores than those reported in the DPTT, emphasising the potential importance of controlling periodontal inflammation using effective periodontal therapy, which would include both non-surgical and surgical management of gum inflammation in the patient population. The use of a standardised periodontal treatment protocol in a single specialist centre might have strengthened our findings; however, whether these 
findings could be replicated in multicentre, larger trials is unclear. Finally, our study participants differed from those in the DPTT: our participants were aged 18 years or older with at least 20 periodontal sites with active periodontal inflammation, whereas in the DPTT, the patients were aged 35 years or older with a minimum of two sites with periodontal inflammation. As a result, a smaller proportion of patients in the DPTT had gum inflammation to start with than in our study. At the end of the DPTT, many of the test patients still had ongoing gum inflammation and could have been re-enrolled into the same study.

In our study, we found improvements in a broad range of secondary outcomes, suggesting an effect of periodontal therapy on cardiovascular and renal complications of diabetes. In a previous randomised clinical trial ${ }^{7}$ in patients without diabetes, we showed that IPT led to significantly improved endothelial function after6 months oftreatment. We now show that this improvement can be maintained up to 1 year in a population with diabetes who are at high risk for cardiovascular disease. Additionally, we report a 1-1\% lower overall UKPDS 10 year risk of cardiovascular disease with IPT than with CPT at 12 months. This estimate must be interpreted cautiously rather than as definitive evidence to be applied in clinical practice. Findings from the UKPDS for metformin or insulin versus conventional glucose lowering with diet restriction showed only a marginal improvement in cardiovascular mortality despite a $0-9 \%$ reduction in $\mathrm{HbA}, /^{\prime}$ Periodontal treatment might improve overall cardiovascular risk beyond the glucose lowering effect; if demonstrated in larger intervention trials, periodontitis might represent a novel preventable cause of vascular complications in patients with diabetes.

The change in $\mathrm{HbA}^{\prime}$ was accompanied by improved eGFR in our study, suggesting a causal relation between periodontitis and increased renal and cardiovascular complications, as has been postulated from at least one observational study. ${ }^{25}$ Glomerular endothelial damage is regarded as an early step in the evolution of diabetic nephropathy. ${ }^{26}$ A reduction in the thickness of the endothelial glycocalyx has been described in patients with early stages of diabetic nephropathy!' and the observed beneficial effect ofiPT on endothelial function might link the improvements in FMD and renal function that we observed.

The IPT group reported better diabetes-related quality of life than the CPT group in our study. A systematic review" found that no relevant studies reported data on quality of life; a gap partly addressed by our study. Our results showed that the overall improvements were mainly due to increased psychological and functional aspects of quality of life, with differences reported in both self-confidence and living conditions. Furthermore, IPT resulted in improvement of the working life of patients with diabetes, highlighting the potentially wide societal impact of such treatment.
Inflammation is a known driver of insulin resistance, with a role in the initiation and evolution of cardiovascular and renal complications in patients with and withou1 diabetes. ${ }^{28}$ Our findings support the hypothesis that reduction of periodontal inflammation is associated with reduced systemic inflammation and improved vascular function and metabolic markers, as suggested in a 2015 systematic review. TNFa has been implicated in systemic insulin sensitivity, ${ }^{29}$ and the severity of periodontitis correlates linearly with systemic levels ofTNFa in patients with diabetes. ${ }^{30}$ We saw a linear correlation between reductions from baseline to 12 months in markers of systemic inflammation (CRP and TNFa), periodonta] inflammatory parameters (probing pocket depths, number of deeper periodontal pockets, and gingival bleeding), anc systemic outcomes (metabolic control and vascular anc kidney functions). However, these correlations were no1 seen for measures of insulin production and sensitivity (HOMA2 scores). Previous reports have shown that reduction of inflammation by lifestyle interventions" o1 drug therapy (eg, interleukin-1 antagonists)" increases secretion of insulin from $p$ cells and decreases blooc glucose concentrations in patients with diabetes. In a large secondary prevention trial ${ }^{33}$ of patients at high risk of cardiovascular diseases and other comorbidities including type 2 diabetes, treatment with an interleukin-1p inhibitor (canakinumab) significantly lowered the rate of recurren1 cardiovascular events versus placebo; this result was independent from the reductions in lipids achieved with drugs. Whether treatment of periodontitis, and the associated reduction in systemic inflammation, coulc produce similar benefits on outcomes such as cardiovascular and renal events in patients with type 2 diabetes could be addressed in future studies.

Our study has some limitations. In particular, our findings could be partly attributed to the effect of non-diabetes medications. Patients in the CPT and IPT groups presented with some differences in their use of aspirin, p blockers, and angiotensin-II blockers at baseline. We cannot exclude that medications used might have contributed to the differences in $\mathrm{HbA}$, between study groups at 12 months. However, a post-hoc sensitivity analysis in subgroups of patients not taking these medications lent support to a consistent reduction in $\mathrm{HbA}$, in the IPT group compared with the CPT group. Future studies should address the efficacy of periodontal treatment in patients with type 2 diabetes during treatmen1 with different cardiometabolic drugs. We did this study in a single university centre and patients with moderate-tosevere periodontitis were treated for 12 months. We acknowledge a potential recruitment bias in this study and urge caution in extrapolating the results to all patients with type 2 diabetes; nevertheless, we aimed to reduce bias by recruiting from both hospital and primary-care recruitment centres (dental and medical).

Global prevalence of periodontal diseases is higher than $50 \%$. In people with diabetes, the prevalence of severe 
forms of periodontitis is almost $50 \% .^{34}$ Our findings highlight the potential to improve metabolic control and possibly diabetes outcomes by addressing poor oral health in those with diabetes. Longer and larger studies are needed to determine whether the benefits we have shown are sustained beyond 12 months, are broadly applicable tc people with type 2 diabetes, can reduce morbidity and mortality, and can improve quality oflife in the long term. If confirmed in larger trials, diabetes care should incorporate routine oral health assessment and treatment as part oflifelong disease management.

Contributors

FD'A, SH, ADH , ND, and )ED conceived of and designed the study FD'A, NG, DB, MO, JS, GT, and members of the TASTE Group (appendix) collected data. Members of the TASTE Group and MO did the laboratory analyses. FD'A, SH, TK, SM, ADH, GT, ND, and )ED interpreted the data FD'A, SH, TK, SM, ADH, GT, ND, and JED drafted or critically revised the report. All authors approved the final submitted version of the report. FD'A, ND, and]ED had full access to all the data in the study and had final responsibility for the decision to submit for publication.

Declaration of interests

We declare no competing interests.

Acknowledgments

The study was funded by two grantsfrom Diabetes UK (08f0003594and 08/0003741) and by the UK Department of Health's National Institute for Health Research Biomedical Research Centre at University College LondonfUniversity College London Hospitals. FD'A held a Clinical Senior Lectureship Award supported by the UK Clinical Research Ccllaboration. )ED holds a British Heart Foundation chair and is a National Institute for Health Research senior investigator.

References

1 Tuomi T, Santoro N, Caprio S, Cai M, Weng J, Groop L. The many faces of diabetes: a disease with increasing heterogeneity Lancet 2014; 383: 1084-94

Donath MY, Shoelson SE. Type 2 diabetes as an inflammatory disease. Nat Rev Immunol 2011; 11: 98--107.

Lalla E, Papapanou PN. Diabetes mellitus and periodontitis: a tale of two common interrelated diseases. Nat Rev Endocrinol2011; 7:738--48.

4 Bartold PM, Van Dyke TE. Periodontitis: a host-mediated disruption of microbial homeostasis. Unleaming learned concepts. Periodontol2000 2013; 62: 203-17

Artese HP, FozAM, Rabelo MS, etal. Periodontal therapy and systemic inflammation in type 2 diabetes mellitus: a meta-analysis. PLoS One 2015; 10: e0128344

6 Borgnakke W S, Ylostalo PV, Taylor GW, Genco Rj. Effect of periodontal disease on diabetes: systematic review of epidemiologic observational evidence.] din Periodontol2013; 40 (supp114): S135 52

7 Tonetti M S, D'Aiuto F, Nibali L,et al. Treatment of periodontitis and endothelial function. N Engl] Med 2007; 356: 911-20.

8 Simpson TC, Weldon JC, Worthington HV, et al. Treatment of periodontal disease for glycaemic control in people with di abetes mellitus. Cochrane Database Syst Rev 2015; 11: CD004714.

Wang X, Han X, Guo X, Luo X, Wang D. The effect of periodontal treatment on hemoglobin Ale levels of diabetic patients: a systematic review and meta-analysis. PLoS One 2014; 9: e108412.

10 American Diabetes Association. 2. Classification and diagnosis of diabetes. Diabetes Care 2016; 39 (suppll): S13-22.

11 Altman DG, Bland )M. Treatment allocation by minimisation. BM] 2005; 330: 843 .

12 Allen DR, Caffesse RG. Ccmparison of results following modified Widman flap surgery with and without surgical dressing. J Periodontol1983; 54: 470-75.

13 Tonetti MS, Claffey N. Advances in the progression of periodontitis and proposal of definitions of a periodontitis case and disease progression for use in risk factor research. Group C consensus report of the 5th European Workshop in Periodontology]din Pericdontol 2005; 32 (supp1 6): 210-13.
14 Bradley C, Todd C, Gorton T, Symonds E, Martin A, Plowright R. The development of an individualized questionnaire measure of perceived impact of diabetes on quality of life: the ADDQoL. Qual Lift Res 1999; 8: 79-91.

15 Stevens LA, Ccresh], Greene T, Levey AS. Assessing kidney function-measured and estimated glomerular filtration rate. $N$ Engl] Med 2006; 354: 24733.

16 Charakida M, Masi S, LuscherTF, Kastelein JJ, Deanfield )E. Assessment of atherosclerosis: the role of flow-mediated dilatation. Eur Heart] 2010; 31: 2854-61.

17 Hox JJ. Applied multilevel analysis. Amsterdam: ERIC Clearinghouse, 1994

18 United Kingdom Prospective Diabetes Study Group. United Kingdom Prospective Diabetes Study 24: a 6-year, randomized, controlled trial comparing sulfonylurea, insulin, and metforrnin therapy in patients with newly diagnosed type 2 diabetes that could not be controlled with diet therapy. Ann Intern Med 1998; 128: 165-75.

19 Monami M, Lamanna C, Marchionni N, Mannucci E. Comparison of different drugs as add-on treatments to metformin in type 2 diabetes: a meta-analysis. Diabetes Res din Pmct 2008; 79: 196-203.

20 Sun WL, Chen LL, Zhang SZ, Wu YM, Ren YZ, Qin GM. Inflammatory cytokines, adiponectin, insulin resistance and metabolic control after periodontal intervention in patients with type 2 diabetes and chronic periodontitis. Intern Med 2011; 50:1569-74.

21 )ones JA, Miller DR, Wehler C), et al. Does periodontal care improve glycemic control> The Department of Veterans Affairs Dental Diabetes Study.]Clin Pericdontol2007; 34: 46-52.

22 Chen L, Luo G, Xuan D, et al. Effects of non-surgical periodontal treatment on clinical response, serum inflammatory parameters, and metabolic control in patients with type 2 diabetes: a randomized study J Pericdontol2012; 83: 435-43.

23 Engebretson SP, Hyman LG, Michalowicz BS, et al. The effect of nonsurgical periodontal therapy on hemoglobin Ale levels in persons with type 2 diabetes and chronic periodontitis: a randomized clinical trial. JAMA 2013; 310: 2523-32.

24 Stevens RJ, Kothari V, Adler AI, Stratton !M. The UKPDS risk engine: a model for the risk of coronary heart disease in type I!diabetes (UKPDS 56). Clin Sci (Land) 2001; 101:671-79.

25 Saremi A, Nelson RG, Tulloch-Reid M, et al. Periodontal disease and mortality in type 2 diabetes. Diabetes Care 2005; 28: 27-32.

26 Satchel! S. The role of the glomerular endothelium in albumin handling. Nat Rev Nephrol2013; 9:717-25.

27 Salmon AH, Satchel! SC. Endothelialglycocalyxdysfunction in disease: albuminuria and increased microvascular permeability. J Pathol2012; 226: 562-74.

28 Hotamisligil GS. Inflammation and metabolic disorders. Nature 2006; 444: 860--67.

29 Shoelson SE, Lee], Goldfine AB. Inflammation and insulin resistance. TClin Invest 2006;116: 179 3-801.

30 Engebretson S, Chertog R, Nichols A, Hey-Hadavi], Celenti R, Grbic ). Plasma levels of tumour necrosis factor-alpha in patients with chronic periodontitis and type 2 diabetes.]Clin Periodontol2007; 34: $18-24$

31 Schellenberg ES, Dryden DM, Vanderrneer B, Ha C, Korownyk C. Lifestyle interventions for patients with and at risk for type 2 diabetes: a systematic review and meta-analysis. Ann Intern Med 2013; 159: 543-51.

32 Goldfine AB, Fonseca V, Shoelson SE. Therapeutic approaches to target inflammation in type 2 diabetes. Clin Chem 201 1; 57: 162--<57.

33 Ridker PM, Everett BM, Thuren T, et al. Antiinflammatory therapy with canakinumab for atherosclerotic disease. $N$ Engl] Med 2017; 377: 1119-31.

34 White DA, Tsakos G, Pitts NB, et al. Adult Dental Health Survey 2009: common oral health conditions and their impact on the population. Br Dent] 2012; 213:567-72. 